\title{
Leigh Hunt's New World Forebears
}

DESMOND LEIGH-HUNT

It would be difficult to think of four Englishmen more English than Keats, Shelley, Byron, and Leigh Hunt, who were contemporaries in that golden age of English literature. Leigh Hunt's mother, Mary Shewell, however, was an American, and of six brothers and two sisters, only he and one sister (who died as a child) were born in England. All the others were born in America.

Leigh Hunt's father and grandfather were born in Barbados. Records at Cambridge University in England state that his great-grandfather, Reverend Dr. Brian Hunt, who was born in Kent in the late sixteen hundreds, was admitted to Corpus Christi in 1704. In 1722, according to Fothergill's Emigrant Ministers, he was sent to Virginia, and the following year he became a missionary with the Society for the Propagation of the Gospel in South Carolina. He went to Barbados in 1731 to be rector of St. Joseph's in Bridgetown. He died in 1744.

For a portion of these final years, Brian Hunt's son, Reverend Isaac Hunt (Leigh Hunt's grandfather), was curate of the parish church of St. Michael in Barbados, which would indicate that there was a period during which father and son played concurrent roles in Bajan religious life. Isaac Hunt died in 1759 and is buried in the chancel of St. Michael's Church.

In the circumstances, it is perhaps surprising that Leigh Hunt's father, born in Barbados and also named Isaac, chose not to follow a religious calling. Instead, after having been educated at the William Smith College in Pennsylvania, he elected to study law, eventually obtaining a degree in Philadelphia.

He was a handsome and theatrical man with a magnificent voice (which, Leigh Hunt said, he "modulated with great effect"), and when he delivered the farewell oration at his graduation ceremony, a young girl of impeccable Quaker background fell in love with him. This was Mary Shewell, who became his wife on June 17, 1767. The appeal to a religious, demure, peace-loving Philadelphia girl of a flamboyant, debonair, and uninhibited man from the tropics must have been a source of puzzlement to many. 
Isaac Hunt eventually left Philadelphia under what might be termed rather inelegant circumstances. A staunch Loyalist, he had made quite a name for himself not only by skillfully defending other Loyalists in court, but also as the author of many an impassioned pamphlet championing the cause of the British Crown. The inflammatory nature of these activities, carried out in the face of the revolutionary winds that were blowing at the time, ultimately triggered predictable consequences.

Early one morning in 1775, he was taken from his house ("Conceive," wrote Leigh Hunt, "the anxiety of his wife!") and, along with a Dr. Kearsley, an equally dedicated Tory, was driven about the streets of Philadelphia in an open cart, the intention being eventually to tar and feather both men, neither of whom would submit to intimidation by the angry throngs. Dr. Kearsley, in fact, while being paraded around, and despite having had a hand pierced by a bayonet, made so bold as to sing God Save the King at the top of his voice. It was during this episode that Isaac Hunt had the misfortune to be struck on the head by a rock thrown by a spectator.

At the last minute the two rambunctious Loyalists were spared the ordeal of being tarred and feathered. That final indignity was averted when a friend of Colonel Robert Shewell, Mary Hunt's uncle, managed, in the nick of time, to overturn the tub of hot tar that had been prepared for the purpose.

After having been paraded up one street and down the next, both men were imprisoned, but Isaac Hunt succeeded in bribing a prison guard, and escaped. That same night he boarded one of his father-in-law's ships anchored in the Delaware River and, before dawn, was on his way to Barbados. From there he sailed to England. It was almost two years before his wife was able to join him.

The impact all this revolutionary violence had on Mary Hunt, a gentle woman of pacifist persuasion, is easy to imagine. Her son was probably indulging in a little poetic license when he claimed that his mother's soul had been shaken by the "war-whoops of the Indians which she heard in Philadelphia," but in those frighteningly unstable times she undoubtedly did live in constant fear of terrifying knocks on the door in the middle of the night.

Leigh Hunt maintained, in fact, that on that dreadful day when his father was paraded around Philadelphia by an enraged mob, his mother was so petrified that she had become "jaundiced," and had remained so for the rest of her life. It was to the cumulative effect of these experiences that he was referring when he wrote of his mother: "Never shall I forget her face... with that weary hang of the head on one side, and that melancholy smile!" 
England was Isaac Hunt's home for the rest of his life. It was by no means a happy existence, but he never lost his exuberant spirits. Unable to practice law in England, he followed in the footsteps of his father and grandfather, and took to the pulpit. He soon became extremely popular as a preacher, but money was always in short supply-so much so that he on occasions was confined in debtors' prison.

The American artist Benjamin West had by this time moved from Philadelphia to London, where he later married Elizabeth Shewell, the sister of Isaac Hunt's father-in-law. The saga of "Betsy" Shewell's flight from Philadelphia to join her husband-to-be in London will be recounted later. She and her niece Mary, who had married Isaac Hunt, were not too far apart in age, and for a period Isaac and Mary lived with the Benjamin Wests in London.

Isaac Hunt felt strongly that he had earned a Loyalist pension for having sacrificed so much in taking a stand against the Revolution in America - and he had support on this point. Largely on account of the repeated representations made on his behalf to King George III by Benjamin West (who had become president of the Royal Academy, and enjoyed a close relationship with the king), he was eventually granted a pension of 100 pounds a year, but he was obliged to mortgage this to pay off some of his debts before ever receiving a penny of it.

Toward the end of his life, his sister Elizabeth, who had married into the wealthy Dayrell family of Barbados, came to London, bringing along her two daughters, her unmarried sister Ann Courthope, and a Black slave named Solomon from her Barbados estate. She gave her brother considerable financial assistance and, as Leigh Hunt put it, "My father's West Indian sun was once again warm upon him."

Isaac Hunt's characteristic enthusiasm for life finally became tinged with bitterness, however, and his son probably made a shrewd and pertinent observation when he wrote: "My father was a true exotic, and ought never to have been transplanted." Certainly it would be hard to imagine two more contrasting life-styles than a debtors' prison in London, and the wealth and tropical luxury he probably would have enjoyed had he returned to Barbados instead of remaining in England. Isaac died in London in 1809 at the age of 57.

Leigh Hunt was naturally very much aware of the profound personality differences between his father and his American mother. "My mother," he wrote, "had no accomplishments but the two best of all, a love of nature and of books." Comparing her with his father, he later wrote: "As I do not remember to have ever seen my mother smile, except in sorrowful tenderness, so my father's shouts of laughter are now ringing in my ears." 
Primarily, no doubt, because of her Quaker upbringing, and perhaps also because of her exposure to revolutionary turmoil in America, it is obvious that the former Mary Shewell of Philadelphia carried her pacifist inclinations to an almost pathological degree. According to her son, the mere sight of two men arguing distressed her greatly, and she would take a long detour, when out walking, in order to avoid the spectacle of soldiers drilling in a park.

Genuine compassion, though, accompanied this pacifism. Although obviously indulging in a little overdramatization, Leigh Hunt, in fact, attributed his mother's chronic rheumatism to a cold she contracted one chilly day after taking off her flannel petticoat and giving it to a destitute woman who had approached her on a London street. While the cause of her rheumatic condition was undoubtedly other than that diagnosed by her son, the incident nevertheless serves as an illuminating insight into the compassionate nature of this woman from America.

Leigh Hunt seems to have been convinced that there was an easily recognizable difference in the physical appearance of Americans. He described his mother as "a brunette with fine eyes, a tall lady-like person, and hair blacker than is seen of English growth," and mentions in his Autobiography that Benjamin West had once told him that, had he met him or any of his brothers on the street, "he would have pronounced, without knowing us, that we were Americans."

He also recounted how his brother Stephen was one day carried off across the Delaware River by Indians, apparently intent on kidnapping the boy because of his "tall little person, dark face, and long black hair." Fortuitously, the child was rescued by an uncle of the same namethough, as it turned out, no one was in a position to save the older Stephen when he later disappeared while sailing from Phildelphia to Barbados. Leigh Hunt speculates that his demise was the direct result of his "crowding too much sail," which he had a reputation for doing in order "to get back to his ladies."

With so much Western Hemisphere blood coursing through his veins and arteries, one would have expected Leigh Hunt to be decidedly proAmerican. Indications are, however, that this he most assuredly was not.

"I cannot get it out of my head," he wrote in his Autobiography, "that the Americans are Englishmen with the poetry and romance taken out of them, and that there is one great counter built along their coast from north to south behind which they are all standing like so many linendrapers."

There is little doubt that he felt he had good reason for his antipathy toward Americans. Certainly he had no love for American publishers 
who, he complained, "do us so much honour in taking our books, and giving us nothing in exchange."

Benjamin Franklin was a close friend of the Shewell family in Philadelphia, and once offered to teach Mary how to play the guitar (an offer she shyly declined), but even he failed to earn any admiration or respect from her son, Leigh Hunt. "From never doing wrong in little things," he wrote of Franklin, "he conceived that he could do no wrong in great; and, in the most deliberate act of his life, he showed he had grievously mistaken himself."

It seems likely, however, that Leigh Hunt's wealthy maternal grandfather, Stephen Shewell of Philadelphia, was perhaps more responsible than any other one person for the way he felt about America and Americans. Not only did Leigh Hunt accuse him of "niggardly conduct" toward his mother, but he resented for the rest of his life a personal insult hurled at him across the Atlantic by his grandfather. If he would come to Philadelphia, Stephen Shewell told his grandson forthrightly, he would make a man of him. "Men," Leigh Hunt shot back at his grandfather, "grow in England as well as America."

Stephen Shewell (whose father Robert had arrived in America from Gloucestershire on June 7,1722 ) was what, in modern parlance, might be called a merchant and a shipping tycoon. Born in Philadelphia on January 29,1727 , he and his brother Joseph owned a fleet of merchantmen that plied the seas, linking Philadelphia not only with the West Indies, but with the countries of Europe as well.

In 1750 Stephen Shewell married Elizabeth Fordham, whose mother came of another wealthy Quaker family, the Bickleys. There was a second link between the Shewell and Bickley families when Abraham Bickley III married Stephen Shewell's sister Mary.

During the Revolution, Stephen steadfastly claimed that he was neutral, and he attempted to carry on business as usual, but there is little question that he was a Royalist at heart. Several of his ships were burned to prevent their falling into the hands of the British, and his home was ransacked on a number of occasions, but the clearest indication of his political inclinations was the fact that for several months he gave secret shelter in the attic of his house to an escaped British prisoner, the captain of an armed vessel seized on the Delaware River.

Without taking too uncharitable a stand, it can probably be said with at least some degree of certainty that Stephen Shewell was not a particularly likable man. As was mentioned earlier, his grandson Leigh Hunt bore considerable ill feeling toward him because of what he alleged was his penurious attitude concerning his daughter Mary, who was, of course, Leigh Hunt's mother. In all fairness, though, the possibility should be suggested that Leigh Hunt might not have been fully aware 
of the financial losses suffered by his American grandfather during the Revolution.

The man who probably described Stephen Shewell best was a Dr. Joseph K. Swift who, in a letter dated February 19, 1858, addressed to Horatio G. Jones, corresponding secretary of the Pennsylvania Historical Society, wrote of him: "He was a proud, imperious man of strong persuasions; a warm friend and an implacable enemy."

Today Stephen Shewell would unquestionably be branded a tyrant, if for no other reason than because of the unconscionable measures he used to derail the love affair that took root between his sister Elizabeth and the artist Benjamin West, whom he considered at that time to be a "pauper" and "an object of charity."

Hearing that they had become engaged to be married, and that Benjamin West planned to sail for Europe, Stephen kept his sister (who had lived with him since the deaths of their parents) under lock and key in her chamber until after the ship, with West aboard, had sailed.

Having eventually established himself as an artist of considerable repute in London, Benjamin West sent for his "Betsy," and arranged for his father to be her chaperone on the long voyage to England. Shewell, however, got wind of the plan, and once again took drastic and immediate action. He sent Elizabeth to Pen Ryn, the Bickley estate on the Delaware River about 14 miles from Philadelphia, with strict orders that she be kept under tight security by her sister Mary. This time, however, his self-appointed role of master of Elizabeth's fate was not successful.

Late at night three male friends, Benjamin Franklin, then 57, an 18year-old "Billy" White, who would later become Bishop of Pennsylvania, and Francis Hopkinson, a future signer of the Declaration of Independence, rescued the incarcerated girl by means of a rope ladder which they attached to her bedroom window.

As soon as she and West's father had boarded the waiting ship, it cast off, dropped down the Delaware River, and set a course for England. Benjamin West was waiting for her on the dock in London, and they were soon married. Neither she nor Benjamin West ever returned to America, and despite repeated attempts on her part to establish a rapprochement with her brother, he steadfastly refused ever again to have anything to do with her.

It is ironic that Stephen Shewell lost much of his wealth during the Revolution, and that most of what he had in later years was the inheritance of his wife Elizabeth Fordham. As stated previously, Elizabeth's mother was a Bickley, a family that arrived in America in 1682, and whose money created one of the few tangible links we have with those bygone days. 
This is the magnificent Pen Ryn estate, now a school, at Bensalem on the northeastern outskirts of Philadelphia. Several Bickleys are buried in the family vault there. Also still in existence is the famous Bickley coach that was imported from England by Abraham Bickley III shortly after his marriage to Mary Shewell in 1758.

It was painted dark green, and was designed to be pulled by four muscular bays. With a coachman and groom on the box, and two liveried footmen on the post board at the rear, it must have been an impressive sight. George Washington certainly thought so. He ordered a replica of it made for his own use.

The coach, with the Bickley crest on the doors, remained at Pen Ryn until 1945, but is now on display at the Brandywine Battlefield at Chaddsford, Pennsylvania. It is called the Lafayette Coach, that great Frenchman having ridden in it on his second visit to the United States in 1825.

Little of the Bickley, Shewell, or Hunt money ever crossed the Atlantic. As a result, Leigh Hunt in England lived his entire life in relative poverty. In retrospect, however, perhaps this was not the tragedy it might seem. One can't help wondering whether the profoundly insightful words of such works as his immortal Abou ben Adhem would ever have flowed from the pen of a man who had been born to inherited wealth. 